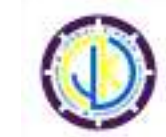

e-ISSN: 2580-6947

p-ISSN: 2354-7278

http://ojs.umrah.ac.id/index.php/kiprah/index

\title{
PENGEMBANGAN LEMBAR KERJA MAHASISWA BERBASIS INKUIRI MATA KULIAH MATEMATIKA UMUM UNTUK MAHASISWA PENDIDIKAN KIMIA
}

\author{
Rezky Ramadhona*, Nur Izzati
}

Universitas Maritim Raja Ali Haji, Kota Tanjungpinang, Kepulauan Riau 29115, Indonesia

\begin{abstract}
Penelitian ini bertujuan untuk mengembangkan Lembar Kerja Mahasiswa (LKM) untuk mahasiswa Program Studi Pendidikan Kimia mata kuliah Matematika Umum berbasis inquiry yang valid, dan praktis. Jenis penelitian yang digunakan adalah penelitian pengembangan dengan tahap pendefinisian (define), perancangan (design), dan pengembangan (develop). Teknik analisis data yang digunakan adalah teknik analisis untuk validasi LKM, praktikalitas LKM. Instrumen pengumpulan data yang digunakan adalah menggunakan Lembar Validasi, dan Angket. Hasil penelitian menunjukkan bahwa LKM valid dari segi didaktik, isi, bahasa, dan penyajian. Selain itu LKM juga praktis dari segi daya tarik, penggunaan dan waktu.
\end{abstract}

Kata Kunci: Lembar kerja mahasiswa, inquiry, matematika umum

\section{PENDAHULUAN}

Matematika merupakan mata pelajaran yang mempunyai peranan penting baik untuk matematika itu sendiri maupun ilmu lainnya. Mengingat pentingnya matematika, maka pelajaran matematika diajarkan kepada siswa mulai dari bangku sekolah dasar sampai bangku perkuliahan. Oleh karena itu matematika juga menjadi mata kuliah pada Program Studi Pendidikan Kimia dengan nama mata kuliah Matematika Umum.

Matematika Umum dipelajari oleh mahasiswa Program Studi Pendidikan Kimia untuk sebagai alat bantu, pembentuk pola pikir, dan pembentuk sikap. Untuk itu dosen harus mampu menumbuhkan motivasi belajar mahasiswa dengan cara membuat mahasiswa tertarik dengan materi yang dipelajari, sehingga hasil belajar yang diperoleh akan lebih baik.

Motivasi merupakan dorongan dalam diri seseorang untuk mencapai tujuan yang diinginkan. Sardiman (2007:73) mengatakan bahwa motivasi belajar adalah keseluruhan daya penggerak di dalam diri siswa yang menimbulkan kegiatan

*Penulis Korepondensi

Email Address : rezkyramadhona@gmail.com belajar, yang menjamin kelangsungan dari kegiatan belajar dan yang memberikan arah pada kegiatan belajar, sehingga tujuan yang ingin dicapai oleh subjek belajar itu dapat tercapai. Seorang mahasiswa yang belajar dengan motivasi yang tinggi biasanya akan memperoleh hasil yang lebih baik dibandingkan dengan mahasiswa yang mempunyai motivasi rendah dalam belajar. Mahasiswa akan termotivasi dalam belajar matematika jika mereka beranggapan bahwa belajar matematika itu sudah menjadi kebutuhan mereka. Oleh karena itu perlu dirancang suatu pembelajaran yang melibatkan keaktifan mahasiswa, meningkatkan kreatifitas mahasiswa dan pola pikir mereka sehingga pembelajaran matematika terasa menyenangkan.

Metode inkuiri merupakan metode pembelajaran dimana untuk memperoleh pengetahuan dilakukan dengan cara menyelidikinya sendiri. Melalui metode ini, mahasiswa mempunyai kesempatan untuk menemukan sendiri apa yang dibutuhkannya. Metode inkuiri lebih menekankan peran aktif 
mahasiswa baik fisik maupun mental dalam proses pembelajaran. Dosen berperan sebagai orang yang mengarahkan dan membimbing mahasiswa dalam melakukan penemuanpenemuan, sehingga motivasi belajar mahasiswa dan pemahaman konsep mereka dapat meningkat.

Proses penemuan konsep dibimbing melalui Lembar Kerja Mahasiswa (LKM). Trianto (2010:111) menguraikan bahwa LKM adalah panduan mahasiswa yang digunakan untuk melakukan kegiatan penyelidikan atau pemecahan masalah. LKM berisi petunjukpetunjuk kegiatan atau panduan yang digunakan untuk melakukan kegiatan penyelidikan atau pemecahan masalah. Oleh karena itu untuk meningkatkan motivasi belajar mahasiswa maka perlu digunakan Lembar Kerja Mahasiswa berbasis Inkuiri. Berdasarkan latar belakang tersebut di atas maka penulis bertujuan untuk melakukan penelitian dengan judul "Pengembangan Lembar Kerja Mahasiswa (LKM) Berbasis Inkuiri pada Mata Kuliah Matematika Umum untuk Mahasiswa Pendidikan Kimia".

Penelitian ini bertujuan (1) untuk mengembangkan LKM Berbasis Inkuiri pada Mata Kuliah Matematika Umum untuk Mahasiswa Pendidikan Kimia yang valid (2) untuk mengetahui praktikalitas LKM Berbasis Inkuiri pada Mata Kuliah Matematika Umum untuk Mahasiswa Pendidikan Kimia

\section{METODE PENELITIAN}

Penelitian ini merupakan penelitian pengembangan (research and development) dengan menggunakan model 4-D (four-D models) yang terdiri dari empat tahap. yaitu pendefinisian (define), perancangan (design), pengembangan (develop), dan penyebaran (disseminate). Dalam penelitian ini tahap yang digunakan hanya sampai tahap pengembangan.

Instrumen yang digunakan dalam penelitian ini adalah (a) Lembar Validasi. Instrumen ini digunakan untuk mengumpulkan data kevalidan dari LKM berisi aspek penilaian yang terdiri atas syarat didaktik, isi, bahasa dan penyajian (b)
Angket. Instrumen ini digunakan untuk mengumpulkan data kepraktisan yaitu menggunakan angket respon mahasiswa terhadap LKM.

Teknik analisis data yang digunakan adalah (1) Analisis Data Hasil Validasi LKM. Data hasil validasi LKM yang diperoleh, dianalisis terhadap seluruh aspek yang disajikan dengan menentukan Modus dari setiap aspek.

(2) Analisis Kepraktisan LKM, Angket respon mahasiswa terhadap LKM dideskripsikan dengan teknik analisis frekuensi data dengan menggunakan rumus (Riduan,2009:89):

$$
P=\frac{\text { skor item yang diperoleh }}{\text { skor }_{\text {maksimum }}} \times 100 \%
$$

Pengkategorian nilai pencapaian responden digunakan klasifikasi yang ada pada tabel berikut:

\section{Tabel 1. Kategori Kepraktisan LKM}

\begin{tabular}{|l|l|l|}
\hline No & $\begin{array}{l}\text { Tingkat } \\
\text { Pencapaian } \\
(\%)\end{array}$ & Kategori \\
\hline 1 & $90-100$ & Sangat Praktis \\
\hline 2 & $80-89$ & Praktis \\
\hline 3 & $65-79$ & Cukup Praktis \\
\hline 4 & $55-64$ & Kurang Praktis \\
\hline 5 & $0-54$ & Tidak Praktis \\
\hline
\end{tabular}

(Sukmadinata, 2008:72)

LKM layak digunakan jika nilai kepraktisannya $>65 \%$.

\section{HASIL DAN PEMBAHASAN}

Hasil dari penelitian pengembangan yang telah dilakukan adalah sebagai berikut:

Tahap Pendefinisian (define), terdiri dari menganalisis kurikulum, dan menganalisis materi. Hasil analisis kurikulum dan materi menghasilkan Rencana Pembelajaran Semester (RPS). Adapun materi yang dikembangkan pada LKM ini adalah Logika Matematika, Himpunan, Barisan dan Deret Aritmatika, dan Barisan dan Deret Geometri. Konten yang termuat dalam LKM dihubungkan dengan bidang Kimia. Contoh konten yang terdapat pada LKM adalah seperti pada Gambar 1. 


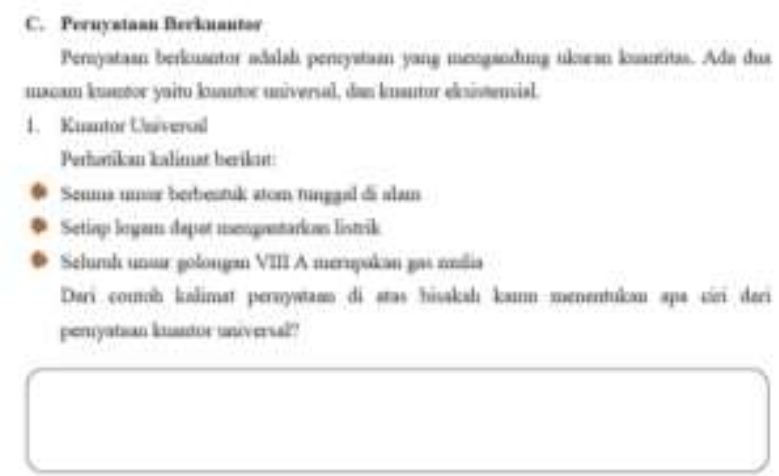

Gambar 1. Konten LKM

1. Tahap Perancangan (Design)

Setelah tahap define dilakukan maka dilanjutkan dengan tahap design yaitu merancang LKM sesuai materi yang telah direncanakan dan merancang instrument pengumpul data yang terdiri dari lembar validasi dan angket respon mahasiswa.

LKM memuat Tujuan Pembelajaran seperti pada Gambar 2.

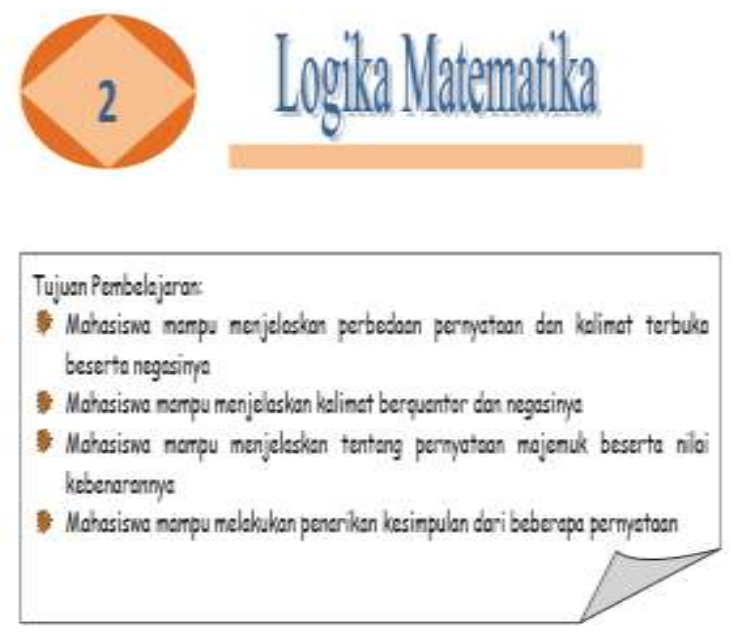

Gambar 2. Contoh Tujuan Pembelajaran

Tujuan pembelajaran dimuat supaya mahasiswa mengetahui tujuan yang akan mereka capai setelah melakukan pembelajaran. Setelah tujuan pembelajaran barulah mahasiswa disajikan dengan permasalahan yang berkaitan dengan bidang Kimia. Selanjutnya mahasiswa dibimbing melalui pertanyaan-pertanyaan sehingga mereka bisa menemukan atau menyimpulkan sendiri konsep yang dipelajari. Contoh pertanyaan dapat dilihat pada Gambar 3.

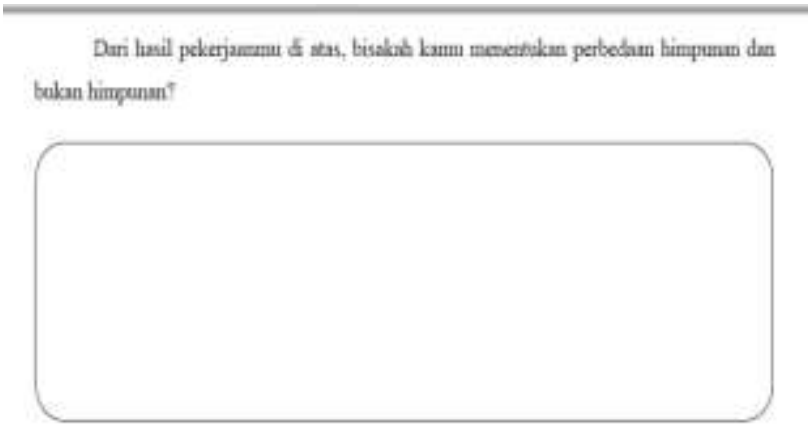

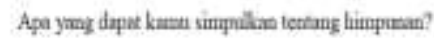

Gambar 3. Contoh Pertanyaan pada LKM

Lembar validasi yang dirancang memuat beberapa pernyataan yang berkaitan dengan aspek didaktik, isi, bahasa dan penyajian. Sedangkan angket yang dirancang terdiri dari sembilan pernyataan yang mencakup aspek daya tarik, penggunaan dan waktu.

\section{Tahap Pengembangan (develop)}

Pada tahap pengembangan, kegiatan yang dilakukan adalah memvalidasi LKM dan mengujicobakan LKM. Validasi dilakukan oleh dua orang dosen, yaitu Dosen Pendidikan Matematika dan Dosen Bahasa Indonesia. Hasil validasi dari dosen mengatakan bahwa Draft LKM valid dari segi didaktik, bahasa, isi dan Penyajian. Secara umum Draft LKM dapat digunakan dengan revisi sedikit.

Draft LKM yang telah direvisi diuji cobakan kepada subjek uji coba untuk melihat tingkat praktikalitas dari LKM. Subjek uji coba yaitu mahasiswa program studi Pendidikan Kimia tahun ajaran 2018-2019 yang berjumlah 33 orang. Uji coba dilakukan sebanyak dua kali pertemuan yaitu pada pertemuan ke 3 dan ke 4 dengan menggunakan Draft LKM Logika Matematika dan Himpunan Matematika. Setelah uji coba dilakukan maka mahasiswa mengisi angket yang telah disediakan untuk melihat praktikalitas dari LKM yang dibuat.

Hasil uji praktikalitas LKM dapat dilihat pada Tabel 2. 
JURNAL KIPRAH, Desember 2018; V1(2): 21-24

e-ISSN: 2580-6947

p-ISSN: 2354-7278

Tabel 2. Hasil Uji Praktikalitas LKM

\begin{tabular}{|llll|}
\hline $\begin{array}{l}\text { Praktikalitas } \\
\text { Daya } \\
\text { Tarik }\end{array}$ & Penggunaan & Waktu & $\begin{array}{l}\text { Rata- } \\
\text { Rata }\end{array}$ \\
\hline $89 \%$ & $91 \%$ & $96 \%$ & $92 \%$ \\
\hline Praktis & $\begin{array}{l}\text { Sangat } \\
\text { Praktis }\end{array}$ & $\begin{array}{l}\text { Sangat } \\
\text { Praktis }\end{array}$ & $\begin{array}{l}\text { Sangat } \\
\text { Praktis }\end{array}$ \\
\hline
\end{tabular}

Dari Tabel 2 dapat dilihat bahwa LKM dilihat dari segi daya tarik adalah praktis, sedangkan dari segi penggunaan dan waktu maka LKM sangat praktis. Secara keseluruhan LKM yang dirancang adalah sangat praktis untuk digunakan dalam pembelajaran.

Berdasarkan hasil uji validitas dan praktikalitas yang telah dilakukan maka dapat disimpulkan bahwa LKM matematika umum sudah valid dan praktis.

\section{KESIMPULAN}

Berdasarkan hasil yang telah dicapai, maka dapat disimpulkan bahwa LKM berbasis inkuiri pada mata kuliah matematika umum untuk mahasiswa pendidikan kimia valid dari segi didaktik, isi, bahasa, dan penyajian serta LKM praktis dari segi daya tarik, penggunaan, dan waktu.

\section{REFERENSI}

Riduan. 2009. Belajar Mudah Penelitian Untuk Guru Karyawan Dan Peneliti Pemula. Bandung: Alfabeta.

Sardiman. 2009. Interaksi dan Motivasi Belajar Mengajar. Jakarta: Rajawali Pers.

Sukmadinata,N. 2008. Metode Penelitian Pendidikan. Bandung:Remaja Rosdakarya.

Trianto. 2010. Mendesain Model Pembelajaran Inovatif dan Progresif. Jakarta: Prenada Media Group 